\title{
EXCLUSION NETS INFLUENCE ON THE ABUNDANCE OF GROUND BEETLES (COLEOPTERA: CARABIDAE) IN APPLE ORCHARDS
}

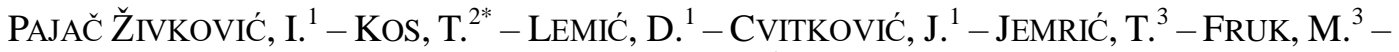 \\ BARIĆ, B. ${ }^{1}$ \\ ${ }^{I}$ Department for Agricultural Zoology, Faculty of Agriculture, University of Zagreb, Croatia \\ ${ }^{2}$ Department of Ecology, Agronomy and Aquaculture, University of Zadar, Croatia \\ ${ }^{3}$ Department of Pomology, Faculty of Agriculture, University of Zagreb, Croatia \\ *Corresponding author \\ e-mail:tkos@unizd.hr \\ (Received $17^{\text {th }}$ Mar 2018; accepted $21^{\text {st }}$ May 2018)
}

\begin{abstract}
Ground beetles (fam. Carabidae) as beneficial insects are valuable organisms to study whether any of the new implemented agricultural measures in fruit production is beneficial. The aim of our study was to analyze impact of different types of exclusion nets on ground beetle species composition and abundance in an apple orchard. The study was conducted in an IPM apple orchard, situated in the northwest part of Croatia. The treatments for the study were four types of exclusion (colored) nets (Agritenax white, Agritenax yellow and Agritenax red all with photo selective properties and Stop Drosophila Normal net - pearl color) and non-covered trees acted as a control. Ground beetles were collected during the summer and autumn (from July $1^{\text {st }}$ until October $15^{\text {th }}$ in 2015) with pitfall traps. During the study, a total of 1559 specimens of ground beetles were identified and sorted into 28 species. Significant differences in the captures under nets were observed for species: Anchomenus (Anchomenus) dorsalis (Pontoppidan 1763), Microlestes minutulus (Goeze 1777), and Pterostichus (Feronidius) melas melas (Creutzer 1799). The most of the ground beetles (413) were recorded under the Agritenax yellow nets and the least (184) in the control. Our study showed the positive effect of exclusion nets on ground beetle species composition and diversity in IPM apple orchard thus confirming their value in assessing the introduction of new agricultural measures into practice.
\end{abstract}

Keywords: Agritenax and Stop Drosophila Normal net, Croatia, IPM fruit production, pitfall traps, soil dwelling fauna

\section{Introduction}

Ground beetles (Coleoptera: Carabidae) are beneficial organisms as predators of various pests in different developmental stages in agricultural production (Lövei and Sunderland, 1996; Kromp, 1999). Their communities are not bound to a certain crop type, but shift in dominance according to the crop-specific rhythm of cultivation and changes in crop phenology and microclimate (Kromp, 1999). Any change in agricultural practices, especially novel practices, can directly affect ground beetles. Because they are highly sensitive to anthropogenic impacts, ground beetles can be considered as bioindicators of environmental impacts from cultivation practices (Kromp, 1999). The composition and richness of Croatian ground beetle fauna have been studied in a variety of arable crops represented in different agricultural practices (e.g. alfalfa and red clover, winter wheat and barley, maize, sugar beet and vegetable gardens) (detail described in: Kovačević and Balarin, 1960; Sekulić et al., 1973; Bažok et al., 2007; Stančić, et al., 2010; Kos et al., 201201 2013; Lemić et al., 201 2017; Drmić et al., 2016; Virić et al., 
2017). Clearly there have been few studies of changes in ground beetle communities in response to orchard production, and particularly to those agricultural and crop protection practices that are now standard in apple production.

The standard method for crop protection in Croatian apple orchards is Integrated Pest Management (IPM), which is a suite of environmentally and toxicologically acceptable procedures to control pest populations. Those measures could affect activity, density and species richness of apple orchard ground beetle communities. A new approach of applying colored photo selective shade nets (exclusion nets; anti-hail nets) for improving the utilization of solar radiation by fruit trees was introduced in practice recently (Shahak et al., 2004). The photo selective netting in apple orchard has a positive effect on flowering, fruit-set, fruit size, color and internal quality, in addition to non-specific reduction of water stress, superficial damage and sunburn (Shahak et al., 2004). The main reason to set up the exclusion nets during this study in IPM Croatian orchards was to test their effectiveness in preventing codling moth to apple fruits (Pajač Živković et al., 2016). This experiment resulted in a highly significant reduction of codling moth in IPM orchards (Pajač Živković et al., 2016). The main consequence of applying exclusion nets is the change in the microclimate beneath the trees, accordingly any change of this kind could lead to a disturbance and towards affect orchard ground beetle communities. Therefore, we hypothesized that exclusion nets could have a negative impact on ground beetles in IPM orchards.

The main objective of this study was to define and analyze what type of exclusion net has the least negative impact on ground beetle abundance and diversity in an IPM Croatian apple orchard.

\section{Materials and methods}

\section{Study area}

The study was conducted in an IPM apple orchard (46 9'47'N, 15'52'52'E), situated in north-west Croatia (Krapina County; Fig. 1).

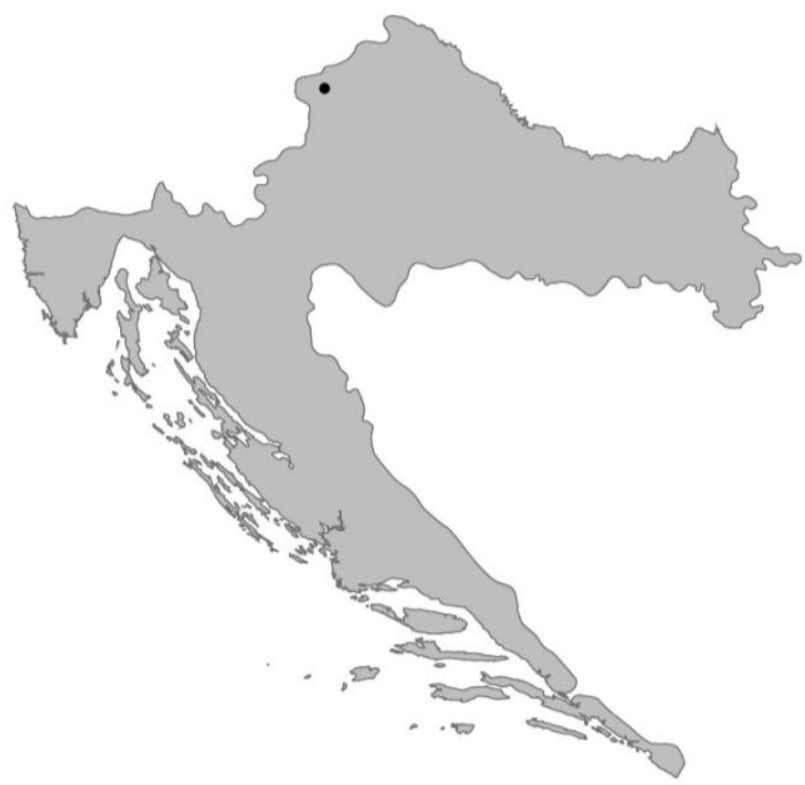

Figure 1. Experimental site in Croatia (Krapina County) 
Beetle collection was carried out during the growing season in 2015. The study area is characterized by a continental-humid climate of warm, rainy summers and cold winters (Penzar and Penzar, 2000). The average annual precipitation in this region is $850 \mathrm{~mm}$ and the average annual temperature is $11{ }^{\circ} \mathrm{C}$ (MHS, 2017). The soil in the study area is typical pseudogley (IUSS Working Group WRB, 2015). The orchard elevation is 282 a.s.l. Apple cultivars of 'Braeburn', 'Idared', 'Golden Delicious', 'Granny Smith' and 'Jonagold' are grown on a surface of $600 \mathrm{~m}^{2}$. During the study period, insecticide treatments were not applied on the experimental site in order to exclude their impact on orchard entomofauna. Fungicides were applied by standard IPM principles in order to maximize apple health and minimize the risk of economic and ecological threats for the environment. Weeds are managed by mulching treatments between rows several times in the season, and vegetation in the row was not treated with herbicides. The orchard is surrounded by agricultural fields (arable crops and grasslands).

\section{Experimental design}

Experimental design was a random block arrangement with four treatments in three repetitions. The treatments were four types of exclusion nets (Agritenax white, Agritenax yellow, Agritenax red - photo selective ones and Stop Drosophila Normal net - pearl color) and non-covered trees as a control. Agritenax nets produced by Tenax S.r.l., Italy were of the same density $(2.4 \times 4.8 \mathrm{~mm})$ while Stop Drosophila Normal net, produced by Artes Politecnica, Italy was of $0.9 \times 1 \mathrm{~mm}$ in density. Each treatment was placed on three neighboring trees, while in three cases neighboring trees were uncovered with exclusion nets what represented a control plot (Fig. 2).

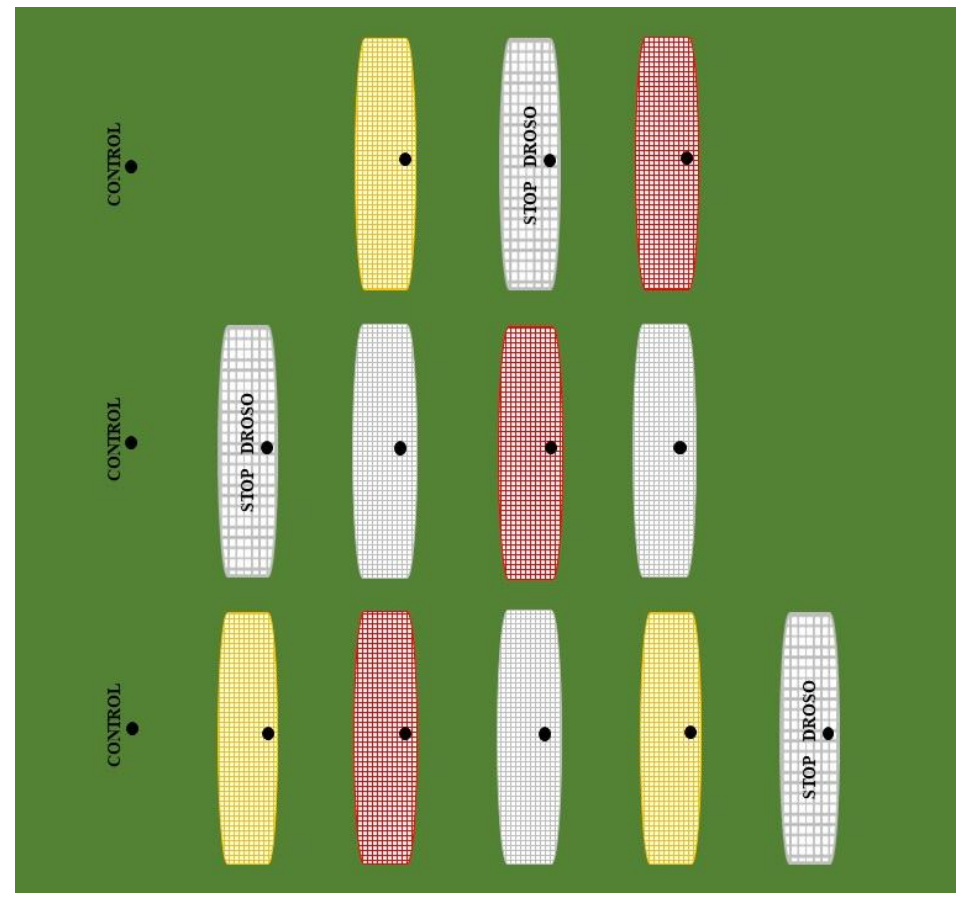

Figure 2. Schematic representation of experimental design

The study occurred in the center of the IPM apple orchard planted with the variety 'Braeburn'. Trees were completely covered with nets and fixed to the ground with metal 
pegs at the petal fall and the nets were removed after the harvest of apple fruits. Before setting up nets, existing arthropod fauna on apple trees were eliminated by applying neonicotinoid insecticide thiacloprid (Calypso ${ }^{\circledR} 480$ SC, Bayer CropScience). One pitfall trap was placed in each treatment in the soil beneath the trees.

\section{Beetle sampling and data analysis}

Ground beetles were collected during summer and autumn (from July $1^{\text {st }}$ until October $15^{\text {th }}$ in 2015) (week 28 till week 42 of the year) with pitfall traps. Traps were a metal cylinder covered with a metal lid $(\varnothing=10 \mathrm{~cm}$ wide and $\mathrm{h}=20 \mathrm{~cm})$. The cylinder was buried in the soil and a round edge plastic southpaw was fitted above. A polythene pot was placed at the bottom of the cylinder. The plastic pot was half filled with saline water (20\% solution) for preservation. For transportation purposes the pots had lids. Traps were inspected on a weekly basis and beetles were preserved in $70 \% \mathrm{EtOH}$ until identification. The identification of the collected ground beetles was based on the works of: Auber (1965), Bechyne (1974), Harde and Severa (1984) and Freude et al. (2006).

The abundance of captured beetles on a weekly base was used as the response variable, and both week and net type, were used as fixed predictor variables in a twofactor analysis of variance, performed separately for each identified beetle taxon. The Tukey honestly significant difference test was used for post-hoc comparisons among means within levels of the two fixed factors (R Core Team, 2017).

\section{Results}

During the study, a total of 1559 specimens of ground beetles were identified and sorted into 28 species represented in Table 1.

The maximum number of specimens, 98 belonged to Pterostichus (Feronidius) melas melas (Creutzer 1799), which is five times the number of specimens of Carabus (Procrustes) coriaceus (Linne 1758), with a total of 196 individuals. In addition to these two species, among the most abundant was Microlestes minutulus (Goeze 1777) with a total of 81 specimens (Table 1).

Table 1. Identified species, captures of species under different net treatments and total capture of species during collection in IPM apple orchard, Krapina, Croatia, 2015 $\left({ }^{*} p<0.05 ; * * p<0.001\right)$

\begin{tabular}{|c|c|c|c|c|c|c|c|c|c|}
\hline Species & A.R. & A.W. & A.Y. & S.D.N & CONT. & $\Sigma$ & Date & $\mathrm{Net}^{\mathrm{o}}$ & Date $\times$ Net \\
\hline Nebria (Nebria) brevicollis (Fabricius 1792) & 0 & 0 & 1 & 0 & 0 & 1 & 0.463 & 0.413 & 0.499 \\
\hline Carabus (Procrustes) coriaceus Linne 1758 & 30 & 50 & 33 & 50 & 33 & 196 & $1.39 \mathrm{e}-14 * * *$ & 0.204 & 0.891 \\
\hline $\begin{array}{l}\text { Brachinus (Brachinus) crepitans (Linne } \\
\text { 1758) }\end{array}$ & 7 & 3 & 9 & 4 & 0 & 23 & $0.0109^{*}$ & 0.3006 & 0.8817 \\
\hline $\begin{array}{l}\text { Trechus (Trechus) quadristriatus (Schrank } \\
\text { 1781) }\end{array}$ & 0 & 0 & 0 & 0 & 1 & 1 & 0.456 & 0.410 & 0.487 \\
\hline $\begin{array}{l}\text { Dinodes (Dinodes) decipiens (L. Dufour, } \\
\text { 1820) }\end{array}$ & 0 & 0 & 1 & 0 & 2 & 3 & 0.0934 & 0.2602 & 0.8331 \\
\hline $\begin{array}{l}\text { Anisodactylus (Anisodactylus) binotatus } \\
\text { (Fabricius 1787) }\end{array}$ & 6 & 6 & 9 & 5 & 3 & 29 & $0.0166^{*}$ & 0.7018 & 0.2131 \\
\hline Harpalus (Harpalus) affinis (Schrank 1781) & 0 & 1 & 1 & 0 & 0 & 2 & $0.0212^{*}$ & 0.5595 & 0.8911 \\
\hline Harpalus (Harpalus) atratus Latreille 1804 & 3 & 7 & 2 & 2 & 6 & 20 & 0.0966 & 0.3998 & 0.3861 \\
\hline
\end{tabular}




\begin{tabular}{|c|c|c|c|c|c|c|c|c|c|}
\hline $\begin{array}{l}\text { Harpalus (Harpalus) dimidiatus (P. Rossi } \\
1790)\end{array}$ & 7 & 11 & 9 & 11 & 7 & 45 & $2.09 \mathrm{e}-07 * * *$ & 0.726 & 0.180 \\
\hline $\begin{array}{l}\text { Harpalus (Harpalus) rubripes (Duftschmid } \\
\text { 1812) }\end{array}$ & 1 & 0 & 0 & 0 & 3 & 4 & $0.049371 *$ & $0.026589^{*}$ & $8.1 \mathrm{e}-05 * * *$ \\
\hline Harpalus (Harpalus) tardus (Panzer 1796) & 1 & 1 & 1 & 2 & 0 & 5 & $0.0212 *$ & 0.7358 & 0.9252 \\
\hline $\begin{array}{l}\text { Pseudoophonus } \\
\text { (Panzer 1796) }\end{array}$ & 2 & 3 & 1 & 1 & 0 & 7 & $9.4 \mathrm{e}-04 * * *$ & 0.366895 & 0.345923 \\
\hline $\begin{array}{l}\text { Pseudoophonus } \\
\text { (De Geer 1774) }\end{array}$ & 1 & 5 & 0 & 12 & 2 & 20 & 0.496 & 0.237 & 0.644 \\
\hline $\begin{array}{l}\text { Ophonus (Hesperophonus) azureus } \\
\text { (Fabricius 1775) }\end{array}$ & 1 & 3 & 1 & 2 & 4 & 11 & $0.0315^{*}$ & 0.6250 & 0.1279 \\
\hline $\begin{array}{l}\text { Ophonus } \quad \text { (Metophonus) } \\
\text { (Schauberger 1932) }\end{array}$ & 0 & 1 & 0 & 0 & 1 & 2 & 0.530 & 0.559 & 0.455 \\
\hline $\begin{array}{l}\text { Ophonus (Metophonus) parallelus (Dejean } \\
\text { 1829) }\end{array}$ & 1 & 1 & 1 & 2 & 2 & 7 & 0.121 & 0.930 & 0.791 \\
\hline $\begin{array}{l}\text { Ophonus (Ophonus) sabulicola (Panzer } \\
\text { 1796) }\end{array}$ & 3 & 2 & 1 & 1 & 4 & 11 & $9.1 \mathrm{e}-04 * * *$ & 0.544563 & 0.999960 \\
\hline $\begin{array}{l}\text { Parophonus (Parophonus) maculicornis } \\
\text { (Duftschmid, 1812) }\end{array}$ & 0 & 0 & 0 & 1 & 0 & 1 & 0.456 & 0.410 & 0.487 \\
\hline Microlestes minutulus (Goeze 1777) & $13^{\mathrm{bc}}$ & $40^{\mathrm{a}}$ & $10^{\mathrm{bc}}$ & $16^{\mathrm{bc}}$ & $2^{\mathrm{c}}$ & 81 & $0.00746^{* *}$ & $0.02031 *$ & 0.44138 \\
\hline Badister (Badister) bullatus (Schrank 1798) & 2 & 0 & 2 & 0 & 0 & 4 & 0.0864 & 0.4096 & 0.7991 \\
\hline $\begin{array}{l}\text { Anchomenus (Anchomenus) dorsalis } \\
\text { (Pontoppidan 1763) }\end{array}$ & $4^{\mathrm{bc}}$ & $10^{\mathrm{bc}}$ & $6^{\mathrm{bc}}$ & $21^{\mathrm{a}}$ & $0^{\mathrm{c}}$ & 41 & $1.39 \mathrm{e}-05^{* * *}$ & $0.00115^{* *}$ & 0.44221 \\
\hline Abax (Abax) exaratus (Dejean 1828) & 0 & 0 & 0 & 2 & 0 & 2 & 0.456 & 0.410 & 0.487 \\
\hline $\begin{array}{l}\text { Pterostichus (Calopterus) } \\
\text { (Duftschmid 1812) }\end{array}$ & 0 & 0 & 2 & 0 & 3 & 5 & 0.651 & 0.227 & 0.542 \\
\hline $\begin{array}{l}\text { Pterostichus (Feronidius) melas melas } \\
\text { (Creutzer 1799) }\end{array}$ & $156^{\mathrm{c}}$ & $209^{\mathrm{bc}}$ & $299^{\mathrm{a}}$ & $219^{\mathrm{bc}}$ & $101^{\mathrm{c}}$ & 984 & $<2 \mathrm{e}-16^{* * *}$ & $4.3 \mathrm{e}-05^{* * *}$ & 0.742 \\
\hline $\begin{array}{l}\text { Stomis (Stomis) pumicatus pumicatus (Panzer } \\
\text { 1796) }\end{array}$ & 0 & 1 & 0 & 0 & 0 & 1 & 0.456 & 0.410 & 0.487 \\
\hline $\begin{array}{l}\text { Calathus (Calathus) fuscipes subsp. graecus } \\
\text { Dejean } 1831\end{array}$ & 5 & 8 & 17 & 4 & 9 & 43 & $0.0218^{*}$ & 0.0686 & 0.5972 \\
\hline $\begin{array}{l}\text { Calathus (Neocalathus) melanocephalus } \\
\text { (Linne 1758) }\end{array}$ & 1 & 0 & 6 & 1 & 1 & 9 & $0.0296^{*}$ & 0.2284 & 0.6879 \\
\hline Amara (Amara) ovata (Fabricius 1792) & 0 & 0 & 1 & 0 & 0 & 1 & 0.463 & 0.413 & 0.499 \\
\hline$\Sigma$ (total) & 244 & 362 & 413 & 356 & 184 & 1559 & & & \\
\hline
\end{tabular}

Abbreviations: A.R. - Agritenax red; A.W. - Agritenax white; A.Y. - Agritenax yellow; S.D.N. - Stop Drosophila Normal; CONT.

- No net, control

Different letters indicate significantly different treatment levels

The population dynamics of the most abundant species under different exclusion nets and on the control is shown in Figures 3,4 and 5. Significant captures of species $P$. melas melas started on all treatments from August $13^{\text {th }}$ and lasted till the end of monitoring period. During September two stresses for the population were detected, the first lasted from August $27^{\text {th }}$ to September $3^{\text {rd }}$ while the second lasted from $17^{\text {th }}$ to $24^{\text {th }}$ September. The trend of captures under all nets as well as on the control during the study period was more or less uniform (Fig. 3).

The first significant increase in captures of $C$. coriaceus started on all treatments in the first half of September and the most ground beetles were collected at the beginning of October. A significant number of adults have been captured till the end of monitoring period (Fig. 4). 


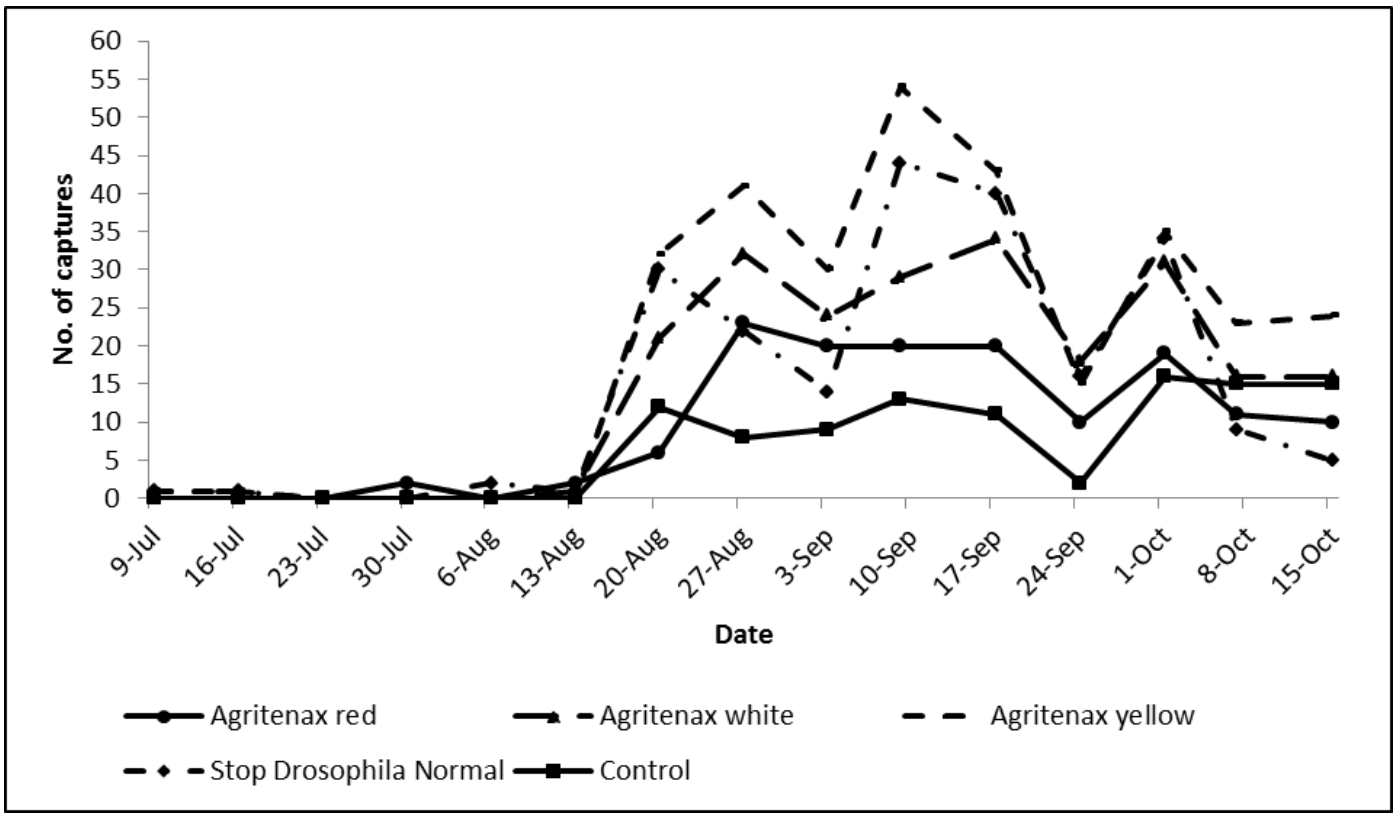

Figure 3. Population dynamic of species Pterostichus melas melas in IPM apple orchard under different exclusion nets and on the control

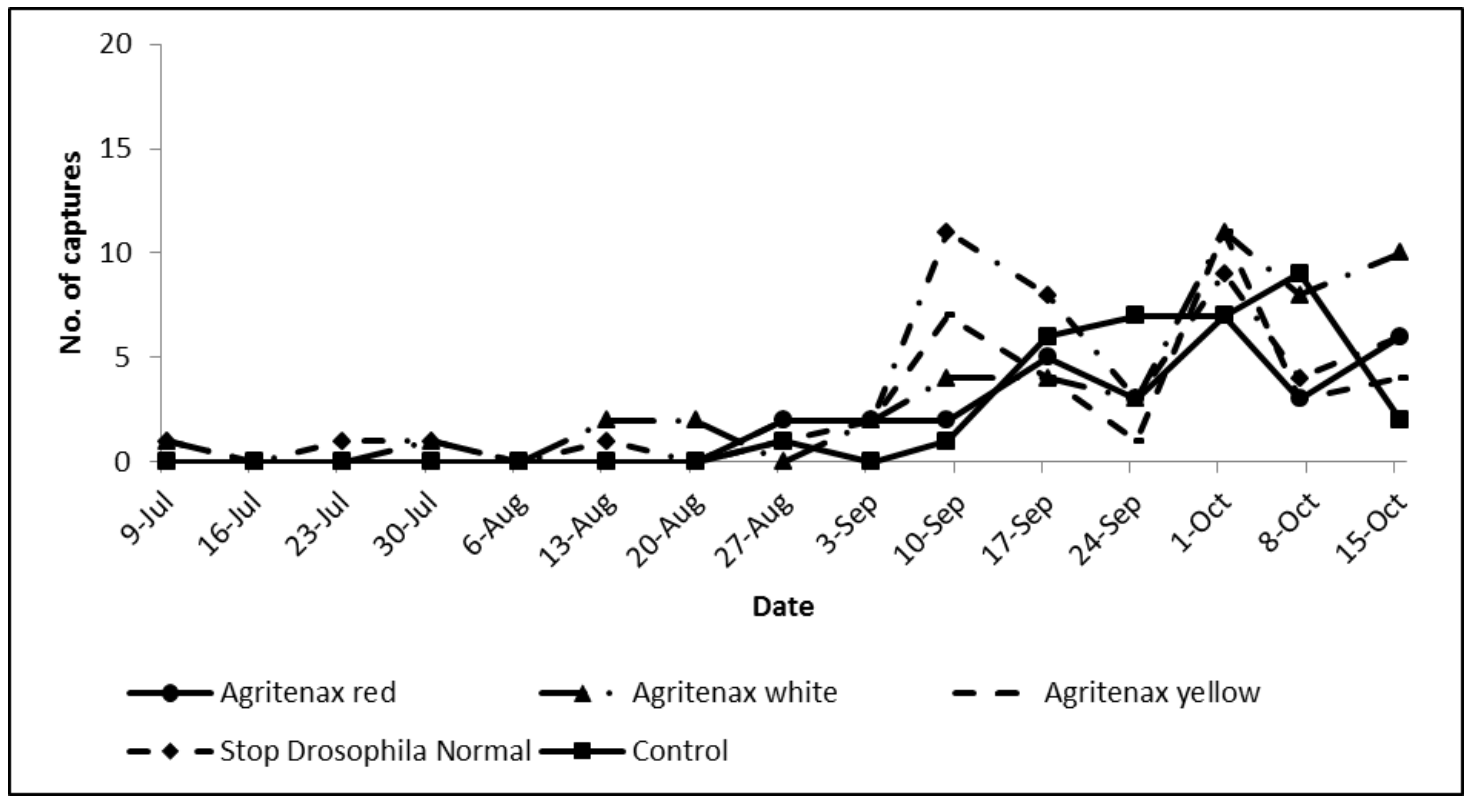

Figure 4. Population dynamic of species Carabus coriaceus in IPM apple orchard under different exclusion nets and on the control

The captures of species $M$. minutullus started on all treatments at the end of July and lasted until the beginning of October. Greater stress for the population of this species occurred from $3^{\text {rd }}$ to $10^{\text {th }}$ of September when the capture fell suddenly on all traps. Under Agritenax white nets captures were higher in September than in August, while the captures under the Agritenax red nets as well as on the control were higher at the beginning of August compared to September (Fig. 5). 


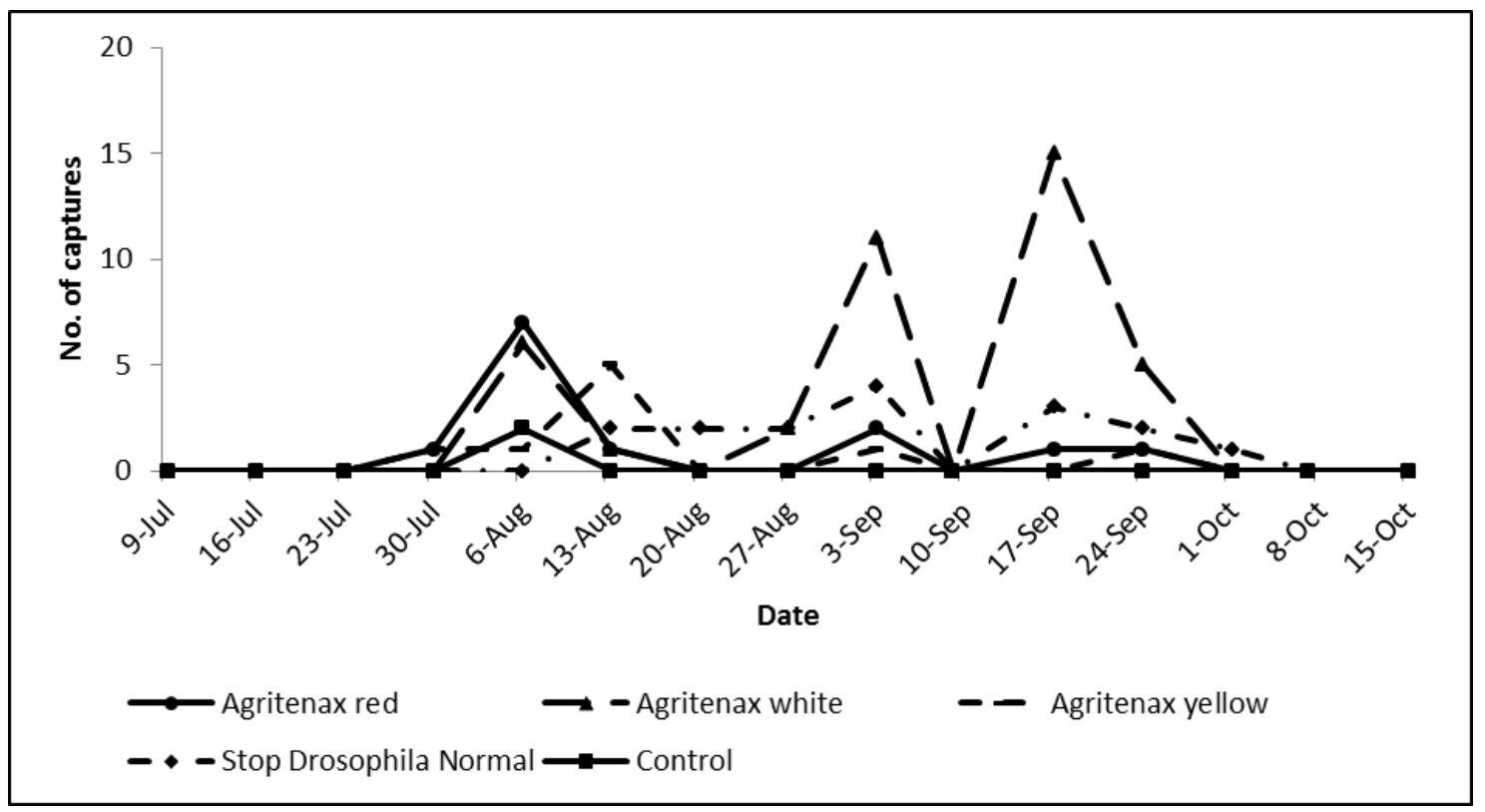

Figure 5. Population dynamic of species Microlestes minutulus in IPM apple orchard under different exclusion nets and on the control

The biggest catch of one species of ground beetles under one type of exclusion nets was 299 and belonged to P. melas melas under Agritenax yellow nets. During the study just one individual of Anchomenus (Anchomenus) dorsalis (Pontoppidan 1763) and Nebria (Nebria) brevicollis (Fabricius 1792) were captured.

The most ground beetles (413) were recorded under the Agritenax yellow nets and the least (184) on the control (Table 1). Significant effects of time of capture were observed generally for more abundant species. Extremely high $(\mathrm{p}<0.001)$ and high $(p<0.01)$ differences between the week of the capture were established on seven species (Table 1). The effect of net type was observed for only four species. A significant interaction between net and time of sampling was observed only for Harpalus (Harpalus) rubripes (Duftschmid 1812). This species was caught in low numbers; therefore because of its rarity further conclusions about it will not be made.

Significant differences in the captures under nets were observed for species $A$. dorsalis, Microlestes minutulus (Goeze 1777), and P. melas melas (Table 2). This study shows that there are significantly more captures of the species A. dorsalis under the Stop Normal Drosophila nets in relation to Agritenax red, white and yellow nets. On the other hand, for the same species, there is a lack of captures on the control. For $M$. minutullus the highest capture was established under Agritenax white nets in relation to Agritenax red and yellow where the captures were significantly lower (Table 2). For this species, captures on the control were the lowest. Captures of adult specimens of the species $P$. melas melas were the highest under the Agritenax yellow nets (Table 2). While captures under Agritenax red and white nets, also as for the Stop Normal Drosophila nets, did not defer statistically. Captures for $P$. m. melas, were similar to those of the other two species, and were the lowest on the control (Table 2).

There was no difference in captures between closely observed species beneath Agritenax red nets and control. P. melas melas had higher rates of captures under the Agritenax yellow nets than other two species in relation to the control. Species of $P$. 
melas melas and M. minutulus were captured more beneath the Agritenax white nets, and P. melas melas and A. dorsalis beneath the Stop Normal Drosophila nets in relation to the control.

Table 2. Tukey adjusted p-values for pairwise differences among all net treatments for species: Anchomenus dorsalis (A.d.), Microlestes minutulus (M.m.) and Pterostichus melas melas (P.m.m.), Krapina, Croatia, 2015

\begin{tabular}{c|c|c|c|c|c|c|c|c|c|c|c|c}
\hline \multirow{2}{*}{ Treatments } & \multicolumn{3}{|c|}{ Agritenax red } & \multicolumn{3}{c|}{ Agritenax yellow } & \multicolumn{2}{c|}{ Agritenax white } & \multicolumn{3}{c}{ Stop Drosophila } \\
Normal \\
\cline { 2 - 11 } & A.d. & M.m. & P.m.m. & A.d. & M.m. & P.m.m. & A.d. & M.m. & P.m.m. & A.d. & M.m. & P.m.m. \\
\hline $\begin{array}{c}\text { Agritenax } \\
\text { red }\end{array}$ & - & - & - & - & - & - & - & - & - & - & - & - \\
$\begin{array}{c}\text { Agritenax } \\
\text { yellow }\end{array}$ & 0.99 & 0.99 & $0.0 * *$ & - & - & - & - & - & - & - & - & - \\
$\begin{array}{c}\text { Agritenax } \\
\text { white }\end{array}$ & 0.77 & 0.14 & 0.67 & 0.93 & 0.08 & 0.16 & - & - & - & - & - & - \\
$\quad$ Stop \\
$\begin{array}{c}\text { Drosophila } \\
\text { Normal } \\
\text { Control }\end{array}$ & $0.01 * *$ & 0.99 & 0.51 & $0.03 *$ & 0.98 & 0.27 & 0.21 & 0.24 & 0.24 & - & - & - \\
\hline
\end{tabular}

$* * 0.001 \leq \mathrm{P} \leq 0.0 * 0.01 \leq \mathrm{P} \leq 0.05$

\section{Discussion}

Various authors have developed different kinds of experiments or have gathered knowledge to prove that the presence of ground beetle, as wide spread beneficial organism, could be an indicator for habitat quality (Bourassa et al., 2008; Avgin and Luff, 2010; Koivula, 2011). Our investigation showed a similar importance for the bioindicative value of this family and their presence in our apple orchard habitat with 28 species found. These results are in a similar range as that of studies in apple orchards from Hungary (Kutasi et al., 2004), Spain (Miñarro et al., 2008), Italy (Paoletti et al., 1995), Canada (Smith et al., 2004) and Japan (Funayama, 2011). Various total captures of ground beetles in our study can suggest that several species should be closely considered for their indicator value because of their abundance, such as P. m. melas; $C$. coriaceus; M. minutulus; Harpalus (Harpalus) dimidiatus (P. Rossi 1790) and A. dorsalis. According to Miñarro and Dapena (2003) the three most common beetles, Pterostichus (Steropus) gallega (Fairmaire 1859), Pseudoophonus (Pseudoophonus) rufipes (De Geer 1774) and Poecilus (Poecilus) cupreus (Linne 1758) represented more than $98 \%$ of the total captures. Those species were not present in our study, but on the other hand our three most abundant species represented more than $75 \%$ of the total captures. Similar results were found in a study from Miñarro et al. (2008) where 83.76\% of all captures were for three of the most abundant species $P$. rufipes $(55.84 \%), P$. cupreus (17.62\%) and Carabus (Tachypus) cancellatus subsp. cancellatus Illiger 1798 $(10.30 \%)$, respectively. The most abundant species, which basically determined the composition of orchard carabid assemblages in study from Markó and Kádár (2005), were Harpalus (Harpalus) froelichii Sturm 181 Harpalus (Acardystus) flavescens (Piller \& Mitterpacher 1783), Calathus (Neocalathus) ambiguus subsp. ambiguus (Paykull 1790), and Harpalus (Harpalus) hirtipes (Panzer 1796). Every agronomic 
practice may influence the environmental variables such as the substrate temperature or humidity, the availability of organic matter, food or shelter, and consequently carabid captures may fluctuate in accordance with their own needs (Miñarro et al., 2008). The exclusion nets also change microclimate conditions (e.g. temperature, relative humidity, light) (Brkljača et al., 2016; Fruk et al., 2016) beneath the net as well as on the soil surface beneath the trees. This practice could influence the richness and diversity of ground beetles. Applying exclusion nets for improving the utilization of solar radiation by fruit trees (Shahak et al., 2004) influences the total capture rate of some ground beetle species. The Agritenax yellow nets had the highest total ground beetle captures among all other nets and the control. Captures varied most likely due to solar radiation, as nets influenced the cover of ground plants or soil humidity beneath the trees, or due to an altered abundance of pests or other fauna. In the study of Miñarro and Dapena (2003) and Miñarro et al. (2008), it was found that ground beetles were captured in the greatest abundance in tilled and herbicide plots compared to mulched plots. In our study, the exclusion nets clearly attracted some ground beetles from the surrounding areas, though the whole orchard was mulched and no herbicides were applied. We observed water condensation on each type of net over the sampling period which implicates that water loss is lower than on the control plots, which is also corroborated by some authors (Wachsmann et al., 2014). Although soil moisture negatively affected carabid catches in cultivated fields (Cárcamo, 1995), in our study exclusion nets might have had the opposite impact. Our sampling period was summer and the beginning of autumn when water loss from the soil is the greatest and ground beetles might be seeking a humid microclimate. It is clear that exclusion nets change the microclimate, which can impact other organisms, such as weeds, which can improve the water balance beneath the apple trees. This could influence prey species richness for ground beetles. Exclusion nets influenced capture rates of three species (A. dorsalis, M. minutullus and P. m. melas). Species of A. dorsalis occur in open meadows and grasslands, usually on soil rich in gravel or clay, and often limestone soil. The species also inhabits arable land, particularly winter crops on heavy soil (Merivee et al., 2012). It is a spring breeder, meaning the species is the most numerous between May and June (Lindroth, 1986). The influence of exclusion nets could be explained mainly by their increase of the preferred (aphid) prey of this species, which is a known aphid predator of cereal crops (Thiele, 1977; Bilde and Toft, 1997). The second important species for this study was the eurytopic $M$. minutulus. It is predominately found at sites with pioneer vegetation or grasses (Brändle et al., 2000) as a typical predator, fully winged. The species is a spring breeder and in this study it was also influenced by exclusion nets. The presence of this species in this study was mostly under Agritenax yellow nets during September. The reason for this could be their preference for prey (aphids) and prolonged vegetation of weeds (grass) under this type of net. The capture of species $P$. melas melas as a predatory, autumn breeder species, that inhabits forests, forest edges, meadows and agricultural land, was also influenced by exclusion nets. Reasons for this, besides prey preference for aphids, might be humidity that attracted another prey, slugs, of the genus Pterostichus (Oberholzer et al., 2003). Slugs were observed in high abundance under exclusion nets. Funayama (2011) considered that only Amara chalcites Dejean 1828 adults can be used as bioindicators for pesticide use pressure in apple orchards in northern Japan, whereas the main diet of this species is probably C3 plants. The results of our study showed that, the selected omnivorous and predatory species of ground beetles are influenced by the exclusion nets, so that they have the potential as 
bioindicators for evaluating the use of netting for improving agricultural habitat. Furthermore, Miñarro et al. (2008) stated that in orchards, groundcover management affected the density and diversity of ground beetles, which is consistent with our study in which exclusion nets have influenced microclimate (humidity) and ground beetle prey attraction.

\section{Conclusion}

The main conclusions of the study are: a) one species of ground beetle could not be considered for bio-indicative value of cultivation impacts and b) most of the captures were for the several most abundant ground beetle species. Considering all of the above, the main hypothesis about the negative impact of the exclusion nets on ground beetles could be rejected as this study indicates a positive effect from exclusion nets on ground beetle abundance in an IPM apple orchard planted with different varieties of apples in north-west Croatia.

Acknowledgements. The authors would like to thank Teun van Gijzen for help with determination of carabid species and Stewart Schultz $\mathrm{PhD}$ for help with statistical data processing in R. Thanks to Ana Gracanin from the University of Wollongong, Australia, for proofreading the manuscript. This study was supported by the European Union from the European Social Fund [grant number: HR.3.2.01-0071] and within the EU projects LIFE+ SU.SA.FRUIT [grant number: LIFE13 ENV/HR/000580] and LIFE+ INSECTLIFE [grant number: LIFE13 ENV/HU/001092].

\section{REFERENCES}

[1] Auber, L. (1965): Atlas des coléoptères de France, Belgique, Suisse. (TOM 1). - Editions N. Boubée, Paris.

[2] Avgin, S. S., Luff, M. L. (2010): Ground beetles (Coleoptera: Carabidae) as bioindicators of human impact. - Mun. Ent. Zool. 5(1): 209-215.

[3] Bažok, R., Kos, T., Igrc Barčić, J., Kolak, V., Lazarević, B., Čatić, A. (2007): Abundance and Distribution of the Ground Beetles Pterostichus melanarius (Illiger, 1798) and Pseudoophonus rufipes (DeGeer, 1774) in Corn Fields in Croatia. - Entomol. Croat. 11(1-2): 39-51.

[4] Bechyne, J. (1974): Welcher Käfer ist das? - Kosmos Natürführer, Stuttgart.

[5] Bilde, T., Toft, S. (1997): Consumption by carabid beetles of three cereal aphid species relative to other prey types. - Entomophaga. 42: 21-32.

[6] Brändle, M., Durka, W., Altmoos, M. (2000): Diversity of surface dwelling beetle assemblages in open-cast lignite mines in Central Germany. - Biodivers. Conserv. 9: 1297-1311.

[7] Brkljača, M., Rumora, J., Vuković, M., Jemrić, T. (2016): The Effect of photoselective nets on fruit quality of apple cv. 'Cripps Pink'. - Agric. Conspec. Sci. 2: 87-90.

[8] Bourassa, S., Cárcamo, H. A., Larney, F. J., Spence, J. R. (2008): Carabid assemblages (Coleoptera: Carabidae) in a rotation of three different crops in southern Alberta, Canada: a comparison of sustainable and conventional farming. - Environ. Entomol. 37(5): 12141223. https://doi.org/10.1093/ee/37.5.1214.

[9] Cárcamo, H. A. (1995): Effect of tillage on ground beetles (Coleoptera: Carabidae): a farm-scale study in Central Alberta. - Can. Entomol. 127: 631-639.

[10] Drmić, Z., Čačija, M., Virić Gašparić, H., Lemić, D., Bažok, R. (2016): Endogaeic ground beetle fauna in oilseed rape field in Croatia. - J. Cent. Eur. Agric. 17(3): 675-684. 
[11] Freude, H., Harde, K. W., Lohse, G. A., Klausnitzer, B. (2006): Die Käfer Mitteleuropas. II Band. Adephaga 1. - Elsevier, München.

[12] Fruk, G., Fruk, M., Vuković, M., Buhin, J., Jatoi, M. A., Jemrić, T. (2016): Colouration of apple cv. 'Braeburn' grown under anti-hail nets in Croatia. - Acta Horticul. Regiotec. 19: 1-4.

[13] Funayama, K. (2011): Influence of pest control pressure on occurrence of ground beetles (Coleoptera: Carabidae) in apple orchards. - Appl. Entomol. Zool. 46: 103-110.

[14] Harde, K. W., Severa, F. (1984): Der Kosmos Käferführer. - Kosmos Natürführer, Stuttgart.

[15] IUSS Working Group WRB (2015): World Reference Base for Soil Resources 201 update 2015. International Soil Classification System for Naming Soils and Creating Legends for Soil Maps. World Soil Resources Reports No. 106. - FAO, Rome. http://www.fao.org/.

[16] Koivula, M. J. (2011): Useful model organisms, indicators, or both? Ground beetles (Coleoptera, Carabidae) reflecting environmental conditions. - ZooKeys 100: 287-317. DOI: 10.3897/zookeys. 100.1533

[17] Kos, T., Bažok, R., Kozina, A., Šipraga, J., Dragić, S., Tičinović, A. (2010): Ground beetle (fam. Carabidae) fauna at treated and untreated barley fields in Croatia. - IOBC WPRS Bulletin 55: 79-84.

[18] Kos, T., Bažok, R., Igrc Barčić, J. (2011): Abundance and frequency of ground beetles in three maize fields in Croatia. - J. Environ. Prot. Ecol. 12(3): 894-902.

[19] Kos, T., Bažok, R., Drmić, Z., Graša, Ž. (2013): Ground beetles (Coleoptera: Carabidae) in sugar beet fields as the base for conservation biological control. - IOBC WPRS Bulletin 90: 353-357.

[20] Kovačević, Ž., Balarin, I. (1960): A contribution to the fauna of Coleoptera and Hemiptera in alfalfa and red clover fields. - Plant Prot. 57/58: 163-175 (in Croatian).

[21] Kromp, B. (1999): Carabid beetles in sustainable agriculture: a review on pest control efficacy, cultivation impacts and enhancement. - Agric. Ecosyst. Environ. 74: 187-228.

[22] Kutasi, C., Markó, V., Balog, A. (2004): Species Composition of Carabid (Coleoptera: Carabidae) Communities in Apple and Pear Orchards in Hungary. - Acta Phytopathol. Entomol. Hung. 39(1-3): 71-89.

[23] Lemić, D., Virić Gašparić, H., Petrak, I., Graša, Ž., Bažok, R. (2016): Utjecaj četverogodišnjeg plodoreda na obnovu korisne faune člankonožaca površinskog sloja tla. - J. Cent. Eur. Agric. 17(4): 1346-1359.

[24] Lemić, D., Čačija, M., Virić Gašparić, H., Drmić, Z., Bažok, R., Pajač Živković, I. (2017): The ground beetle (Coleoptera: Carabidae) community in an intensively managed agricultural landscape. - Appl. Ecol. Env. Res. 15(4): 661-674.

[25] Lindroth, C. H. (1986): The Carabidae (Coleoptera) of Fennoscandia and Denmark. Fauna Ent. Scand. 15: 226-497.

[26] Lövei, G. L., Sunderland, K. D. (1996): Ecology and behavior of ground beetles (Coleoptera, Carabidae). - Annu. Rev. Entomol. 41: 231-256.

[27] Markó, V., Kádár, F. (2005): Effects of Different Insecticide Disturbance Levels and Weed Patterns on Carabid Beetle Assemblages. - Acta Phytopathol. Entomol. Hung. 40(1-2): 111-143. DOI: 10.1556/APhyt.40.2005.1-2.11.

[28] Merivee, E., Must, A., Tooming, E., Williams, I., Sibul, I. (2012): Sensitivity of antennal gustatory receptor neurones to aphid honeydew sugars in the carabid Anchomenus dorsalis. - Physiol. Entomol. 37: 369-378.

[29] MHS, Meteorological and Hydrological Service (2017): Forecasts for the Croatian regions. - http://vrijeme.hr/aktpod.php?id=hrvatska1_n\&param (in Croatian).

[30] Miñarro, M., Dapena, E. (2003): Effects of groundcover management on ground beetles (Coleoptera: CarabidaeI in an apple orchard. - Appl. Soil Ecol. 23: 111-117.

[31] Miñarro, M., Espadaler, X., Melero, V. X., Suárez-Álvarez, V. (2008): Organic versus conventional management in an apple orchard: effects of fertilization and tree-row 
management on ground-dwelling predaceous arthropods. - Agric. Forest Entomol. 10(1): 1-10. DOI: 10.1111/j.1461-9563.2008.00403.x.

[32] Oberholzer, F., Escher, N., Frank, T. (2003): The potential of carabid (Coleoptera) to reduce slug damage to oilseed rape in the laboratory. - Eur. J. Entomol. 100: 81-85.

[33] Pajač Živković, I., Jemrić, T., Fruk, M., Buhin, J., Barić, B. (2016): Influence of different netting structures on codling moth and apple fruit damages in northwest Croatia. - Agric. Conspec. Sci. 81(2): 99-102.

[34] Paoletti, M. G., Scweigl, U., Favretto, M. R. (1995): Soil macroinvertebrates, heavy metals and organochlorines in low and high input apple orchards and a coppiced woodland. - Pedobiologia 39: 20-33.

[35] Penzar, I., Penzar, B. (2000): Agrometeorologija. - Školska knjiga, Zagreb, Croatia (in Croatian).

[36] R Core Team (2017): A language and environment for statistical computing. - $\mathrm{R}$ Foundation for Statistical Computing, Vienna, Austria. https://www.R-project.org.

[37] Sekulić, R., Horvatovich, S., Silješ, J. (1973): A contribution to investigation of family Carabidae in wheat field in the vicinity of Osijek. - Matica Srpska Proceedings for Natural Sciences 44: 85-90 (in Serbian).

[38] Shahak, Y., Gussakovsky, E. E., Cohen. Y., Lurie, S., Stern, R., Kfir, S., Naor, A., Atzmon, I., Doron, I., Greenblat-Avron, Y. (2004): A new approach for light manipulation in fruit trees. - Acta Hort. 636: 609-616. DOI: 10.17660/ActaHortic.2004.636.7.

[39] Smith, R. F., Cossentine, J. E., Rigby, S. M., Sheffield, N. C. S. (2004): Species of ground beetle (Coleoptera: Carabidae) in organic apple orchards of British Columbia. - J. Ent. Soc. Br. Columb. 101: 93-99.

[40] Stančić, Z., Brigić, A., Vujčić-Karlo, S. (2010): The carabid beetle fauna (Coleoptera, Carabidae) of a traditional garden in the Hrvatsko Zagorje region. - Period Biol. 112(2): 193-199.

[41] Thiele, H. U. (1977): Carabid Beetles in their Environments. A Study on Habitat Selection by Adaptation in Physiology and Behavior. Zoophysiology and Ecology 10. Springer Verlag, Berlin.

[42] Virić Gašparić, H., Drmić, Z., Čačija, M., Graša, Ž., Petrak, I., Bažok, R., Lemić, D. (2017): Impact of environmental conditions and agro-technical factors on ground beetle populations in arable crops. - Appl. Ecol. Env. Res. 15(3): 697-711.

[43] Wachsmann, Y., Zur, N., Shahak, Y., Ratner, K., Giler, Y., Schlizerman, L., Sadka, A., Cohen, S., Garbinshikof, V., Giladi, B., Faintzak, M. (2014): Photoselective anti-hail netting for improved citrus productivity and quality. - Acta Hortic. 1015: 169-176. 